\title{
Training Vouchers, Local Employment Agencies, and Policy Styles
}

\author{
Annabelle Doerr · Thomas Kruppe
}

Published online: 29 August 2014

(C) Institut für Arbeitsmarkt- und Berufsforschung 2014

\begin{abstract}
This paper analyzes how the policy style of local employment agencies is correlated with the award intensity of training vouchers for the unemployed - an important instrument of Active Labor Market Policy (ALMP) in Germany. We define the policy style of agencies on the basis of caseworkers' and managers' assessments regarding the voucher system and information on internal organization, cooperative and communicative behavior. We use unique survey data in combination with data on training voucher awards from the Federal Employment Agency. Our results suggest that cooperative behavior and communication have a positive influence on the intensity of training voucher awards after we control for regional and labor market characteristics.
\end{abstract}

Keywords Training Vouchers · Treatment Intensity · Policy Styles

\section{Bildungsgutscheine, regionale Arbeitsagenturen und Politikstile}

This study is part of the project "Regional Allocation Intensities and Reform Effects of Training Vouchers in Active Labor Market Policies", IAB Project number 1155. This is a joint project of the Institute for Employment Research and the University of Freiburg. We gratefully acknowledge financial and material support from the IAB. The usual disclaimer applies.

\section{A. Doerr $(\triangle)$}

Albert-Ludwigs-University, Platz der Alten Synagoge,

79085 Freiburg, Germany

e-mail: annabelle.doerr@vwl.uni-freiburg.de

\section{Dr. T. Kruppe}

Institute for Employment Research, Weddigenstrasse 20-22,

90748 Nürnberg, Germany

e-mail: thomas.kruppe@iab.de
Zusammenfassung In diesem Papier untersuchen wir den Zusammenhang von Politikstilen örtlicher Arbeitsagenturen und der Vergabeintensität von Bildungsgutscheinen, einem der wichtigsten Instrumente der aktiven Arbeitsmarktpolitik in Deutschland. Den Politikstil definieren wir dabei über die Einschätzung von ArbeitsvermittlerInnen und TeamleiterInnen in Bezug auf das Gutscheinsystem, die interne Organisation in den Arbeitsagenturen und deren Kooperations- und Kommunikationsverhalten. Wir benutzen dazu einzigartige Befragungsdaten und prozessproduzierte Daten der Bundesagentur für Arbeit über die Ausgabe von Bildungsgutscheinen. Unter Berücksichtigung regionaler und arbeitsmarktspezifischer Eigenschaften der örtlichen Arbeitsagenturbezirke finden wir Hinweise darauf, dass Agenturen mit einer hohen Kommunikations- und Kooperationsbereitschaft durchschnittlich mehr Gutscheine ausgeben.

\section{Introduction}

Caseworkers and managers at local employment agencies play a key role in the process of assigning unemployed individuals to Active Labor Market Policy (ALMP) programs. They are informed about regional labor market conditions and have expertise in the advantages and disadvantages of different programs for different individuals. Usually, in addition to more rational and objective factors, they will form attitudes and perceptions about different programs that incorporate organizational changes as well as expectations with regard to their own work burden. Accordingly, some programs will be assigned more often than others. In this paper we are interested in the effect that the policy styles of local employment agencies have on the award intensity of training 
vouchers in Germany. The existing literature uses the term policy style as a synonym for political behavior with regard to policy-making and the implementation of policy instruments (Richardson 1982). We focus solely on the implementation of one particular policy instrument in local employment agencies since policy-making takes place at a higher governmental level. We define the policy and implementation style of an agency by using information about the informal behavior of agents within the local employment agency, the internal organization and the degree of openness and cooperation.

In political science there is a large body of literature about the policy-making and implementation styles of nations. $\mathrm{Ri}$ chardson (1982) was one of the pioneers in analyzing policy styles and in investigating the political behavior of decisionmakers in Europe. In general, the literature considers two dimensions of policy styles in hierarchical order. The first dimension focuses on politics in the sense of political power and governmental behavior related to the citizen, opponent parties and interest groups. The second dimension includes the political behavior in particular fields of policy implementation and provides great potential for extracting the policy style and potentially different informal behavior of institutions in an intra-national context (Schiller 1991). The empirical identification and measurement of policy styles gained interest during the last decade. Knodt (1998) contributes to the literature by defining the traditional behavior of regional agents within the concept of policy styles. In this sense she defines policy styles as a set of paradigms, problem-solving mechanisms and cooperative behavior between agents that persist over time. For a detailed overview of the developments of the concept of policy styles see Bauer and Kruppe (2013).

In this paper, we adapt the idea of the policy and implementation styles of political instruments to local employment agencies in the context of a fundamental reform in Germany. To the best of our knowledge, this is the first study that attempts to describe the variation between the award intensity of one important program of ALMP between local employment agencies. Besides structural differences in the unemployment stock and regional conditions, parameters that are likely to incorporate the policy style of employment agencies are taken as explanatory information to learn more about the source of the variation in the use of training vouchers. We use data provided by the German Federal Employment Agency, including the precise numbers of awarded training vouchers between 2005 and 2010 at the level of local employment agencies. We combine this data set with variables describing local labor market conditions and regional characteristics to take into account regional effects and effects that stem from the composition of the unemployment stock. In a further step, we explain the inter-regional variation by parameters related to the policy style of employment agencies regarding the use of training vouchers. The reform of the provision of further training for unemployed individuals in 2003 and 2005 led to substantial organizational changes within the employment agencies that affected the work content and requirements as well as caseworkers' and managers' attitudes regarding further training programs. We use a unique set of survey data that includes information about caseworkers' and managers' attitudes towards the reform in further training as well as information about the organizational structures within the agencies and their cooperative and communicative behavior.

Our results suggest that a high degree of cooperative and communicative behavior is positively correlated with the award intensity of training vouchers when regional and labor market characteristics are controlled for. Sensitivity checks confirm the robustness of this result.

Only few studies apply the policy-style concept to evaluate labor market policies. The study closest to ours is Battaglini and Giraud (2003). They investigate the implementation style of two instruments that promote the reintegration and control of job-seekers in Swiss cantons. They classify the cantons according to their implementation style of the two instruments and explain the differences by analyzing the cantons in qualitative case studies. Their results suggest that the use of one quantitative indicator (scope of state intervention measured as cantonal spending in public employment per capita) makes it possible to classify the cantons according to their orientation towards the two instruments. Dann et al. (2005) are interested in typifying local employment agencies according to their strategies in implementing placement vouchers in Germany. ${ }^{1}$ Applying multivariate methods, they define the organizational structure and the intensity of the instrument as the most important factors. Their results show no specific clusters of local employment agencies with regard to these two dimensions. Breedgard et al. (2003) focus on the implementation processes of municipal labor market policy in Denmark. They assume variation in the implementation of public policies at the level of municipalities and define indicators to describe how policy instruments are implemented. They split the indicators into three groups: 1) administrative and organizational indicators (organization, network cooperation), 2) policy indicators (services, regulations, information) and 3) politics indicators (behaviour of implementing agents). To identify the main dimensions that define the policy style, we rely on the existing literature on policy styles. In this sense we define policy style as the implementation style of the reform instruments in local employment agencies. The policy style can be observed in the organizational structure and in the willingness to cooperate

\footnotetext{
${ }^{1}$ Placement vouchers were implemented in 2002 as an instrument to increase competition between public and private placement activities. See, for example, Winterhager et al. (2006) for detailed information about placement vouchers in Germany.
} 
and to communicate as well as the informal behavior of the agents involved.

The remainder of this paper is structured as follows: The next section provides an overview of the institutional background, focusing on the reform of further training in Germany and its implications for caseworkers and managers at the local employment agencies. In Sect. 3 we discuss the empirical strategy. The data and descriptive statistics are presented in Sect. 4. We present the results and various robustness checks in Sect. 5. The final section concludes.

\section{Institutional background}

The provision of further training to unemployed persons and to individuals who are at risk of becoming unemployed is an important part of Germany's ALMP. Nevertheless, before the so-called Hartz-Reforms were introduced the procedure for assigning unemployed to further training courses and the poor transparency on the training market had come under severe criticism. In January 2003, a voucher system was introduced as part of the First Act for Modern Services on the Labour Market (Erstes Gesetz für moderne Dienstleistungen am Arbeitsmarkt, Hartz I) to overcome existing market failures. The implementation of training vouchers led to fundamental changes for training participants, training providers and employment agencies.

Before 2003, caseworkers were responsible for finding suitable training providers and courses that matched the participants' needs in further training programs. The direct assignment resulted in close relationships between caseworkers and training providers, which was the main source of criticism by federal institutions. The introduction of training vouchers means that the recipients of the voucher themselves now choose the training provider and course. They receive a training voucher containing information about the educational objective, content and duration of the course. ${ }^{2}$ The replacement of the direct assignment by a voucher system implicates some advantages - at least from a theoretical point of view: First, the use of vouchers increases consumer choice and the personal responsibility of potential participants in further training. In this sense the voucher concept is closely linked with the idea of lifelong learning, with the intention of encouraging unemployed individuals to participate actively in the development of their own educational progress. ${ }^{3} \mathrm{Se}-$ cond, the introduction of a voucher system can be seen as a trend towards a market-based and demand-oriented system in the provision of training programs funded at the federal

\footnotetext{
${ }^{2}$ For a detailed description of the voucher system see, for example, Doerr et al. (2014) and Rinne et al. (2013).

${ }^{3}$ The concept of lifelong learning is discussed in a proposal by the Bildung (1999).
}

level. The increased consumer choice was intended to lead to greater competition between training providers and to increase the transparency on the market for further training. ${ }^{4}$

The implementation of a voucher system alters the tasks faced by caseworkers and managers. Prior to the reform, the caseworkers were responsible for assigning unemployed individuals to training courses. Consequently, the reform resulted in a loss of authority in the allocation of training courses that may in turn lead to negative attitudes towards the reform. A positive impact can be seen in the reduced workload for caseworkers. To ensure that training providers offer courses that match the regional demand, caseworkers and managers are expected to publish an annual regional demand forecast for training measures for which vouchers will be issued. Since caseworkers are not allowed to influence voucher recipients' decision as to where to redeem their voucher, problems may occur if, for example, too many training providers offer the same courses in line with the demand forecast while too few training vouchers are redeemed at each particular provider to make the course profitable.

Another source of skepticism results from concerns regarding low-skilled individuals. They may be overburdened with their increased personal responsibility and may be unable to find suitable training providers. Overall, there are reasonable arguments for both positive and negative sentiments towards training vouchers. Some managers and caseworkers support the idea of freedom of choice for the unemployed while others are skeptical.

A further step towards a more market-based system in the provision of further training was taken in January 2005. Based on the Second Act for Modern Services on the Labour Market (Hartz II) a two-stage quality management system for training providers was introduced to integrate quality controls and performance standards in order to ensure that voucher recipients have the opportunity to find high-quality training courses. In a first step, private-sector institutions have to request accreditation from the Federal Employment Agency to become an accredited certification body for training providers (Fachkundige Stellen). In a second step, training providers have to apply to these accredited certification bodies for provider and course certification. To become certified they have to fulfil certain requirements including financial endowment, expertise and an educational concept that defines strategies for reintegrating unemployed individuals into the labor market, offering up-to-date courses and excellent teaching staff. ${ }^{5}$

\footnotetext{
${ }^{4}$ Nevertheless, there seemed to be some sort of market failure as a result of the market power of huge training providers who focussed more on competitive pricing than on quality.

${ }^{5}$ In addition, training providers have to introduce a quality management system. Only quality systems in accordance with ISO 14001 norms
} 
The implementation of the two-stage certification procedure led to a loss of authority for the employment agencies since they are no longer obliged to certify training providers themselves. Nevertheless, they still have a responsibility in the current quality controls for courses. According to a survey conducted shortly after the reform was introduced, communication between local employment agencies and training providers has declined considerably (Schneider et al. 2006). Caseworkers and managers in the agencies are very skeptical about private certification bodies and their work. They argue that private institutions generally have no relation to the special circumstances on the labor market. They focus more on controlling the quality management system than on meeting the specific needs of unemployed individuals. Accordingly, there is a substantial acceptability barrier with regard to the second part of the reform.

Taking this together, the implementation of training vouchers and certification is likely to differ across employment agencies. The employment agencies themselves decide how much of their budget they will spend on further training, which results in a certain number of vouchers being awarded to unemployed individuals. A voucher is only awarded if two stringent requirements are met: there has to be demand for the specific qualification on the labor market and the unemployed person must need this training in order to get back into employment. Therefore, the award of a voucher is a matter of discretion. The decision about the number of vouchers to be awarded may depend upon several more factors. Employment agencies operate under different regional conditions and are faced with a specific composition of their client stock. In addition, it is likely that caseworkers and managers at local employment agencies react in accordance with their sentiments and attitudes towards the reform of the policy instrument.

\section{Empirical Strategy}

The main objective of this study is to explain the variation in the award intensity of training vouchers. We apply a panel regression in the spirit of Hausmann-Taylor to extract the time-constant difference that is not explained by regional differences (Wooldridge 2010). For this purpose we estimate

$$
V I_{i t}=X_{i t}^{\prime} \hat{\alpha}+\bar{X}_{i}^{\prime} \hat{\beta}+\hat{u}_{i t},
$$

where $V I_{i t}$ is the voucher award intensity in employment agency $i$ in year $t$ (with $i=1, \ldots, 173$ and $t=$ $2005, \ldots, 2010) . X_{i t}$ is a vector of time-variant regional and labor market characteristics and $\bar{X}_{i}$ is a vector including the

are allowed. The certification is valid for a maximum of three years, whereas the quality management systems are investigated every year. time-invariant levels of regional labor market conditions in each employment agency district. The time-averaged error term in Eq. (1) defines the variation in the award intensity that remains after controlling for the time-variant and timeconstant differences in regional and labor market characteristics that the employment agencies are faced with. In the following we name this variation $\bar{u}_{i}=\frac{1}{T} \sum_{t=1}^{6} u_{i t}$ as the conditional voucher award intensity of employment agency $i$. The purpose of this study is to characterize this error term and relate it to policy style parameters, such as, for example, different attitudes or the organizational and informal behavior of agents within the agencies. We estimate

$$
\bar{u}_{i}=P S_{i}^{\prime} \hat{\gamma}+\hat{\epsilon}_{i},
$$

where $P S_{i}$ is a vector of policy-style indicators. Thus, the parameter of interest is $\hat{\gamma}$ in (2). To identify $\hat{\gamma}$ we argue that policy styles are constant over time. This is a very strong assumption that is likely to be violated if caseworkers and managers react to past experience and adjust their behavior and attitudes. It is not possible to prove the plausibility of this assumption due to data limitations. A second closely related concern is the possibility of reverse causality. It is possible that the voucher award intensity itself affects the policy style. Those employment agencies with high voucher award intensities communicate and cooperate more often with the other institutions involved because they award a large number of vouchers. The counterargument is that the introduction of the voucher system and the certification management has reduced the authority of local employment agencies considerably. In light of the concerns regarding the underlying assumptions it is important to note that it is not possible to estimate causal effects in this paper. Instead, we present correlations between the agencies' policy styles and training voucher award intensities.

\section{Data and descriptives}

\subsection{Voucher award intensity}

The number of awarded training vouchers at each local employment agency is reported on an annual basis in the internal data of the Federal Employment Agency. We use these data for the years 2005-2010 to calculate the voucher award intensity at each employment agency for every year. For the time period under investigation we observe an increase in the average voucher award intensity from three vouchers per 100 unemployed individuals in 2003 to 37 vouchers per 100 unemployed persons in 2009. In 2010 the award intensity decreased slightly. The rate of training voucher redemption increased continuously from about 90-94\%. 


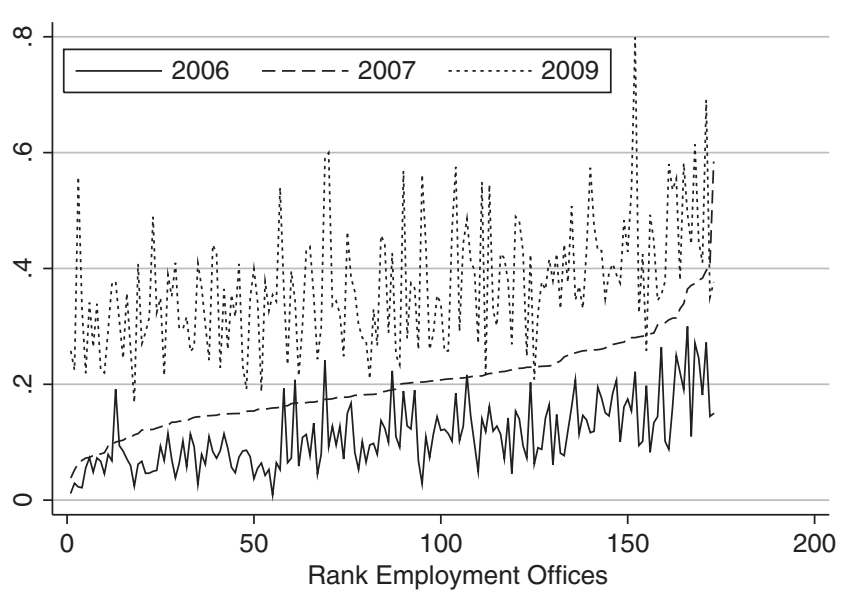

Fig. 1 Trend of voucher award intensity. (Note: We plot the voucher award intensity of 173 local employment agencies for each year based on the rank of agencies in 2007)

As can be seen in Fig. 1, there is a large variation in voucher award intensities between employment agencies and over time. In this figure, we rank the employment agencies with respect to their voucher award intensity in the year 2007 on the abscissa and plot the intensities of later years based on the rank in 2007. ${ }^{6}$ Besides the variation in time, it seems that employment agencies with a high voucher award intensity in early years also show high voucher award intensities in later years. Accordingly, there is a time-constant trend in voucher award intensities between employment agencies. One way to consider this difference is to think about time-constant differences in regional and labor market characteristics. We take into account the differences in regional and labor market conditions using precise information on the regional characteristics and the characteristics of the unemployed persons registered at a certain employment agency, for example the share of old and young individuals, and the industry structure in the region over a time period of 6 years. ${ }^{7}$

In Fig. 2 we show the regional dimension in the variation of the voucher award intensity for some of the years under investigation. The voucher award intensities for all employment agencies are reported in quartiles for each year. We observe a time-constant difference between the eastern and western parts of Germany, with most of the employment agency districts in eastern Germany having low award intensities distributed within the two lowest quartiles. In contrast, there are regions with very high intensities for all of the time periods, for example the employment agency districts in Bavaria and in the Ruhr Area. Very most northerly employment

\footnotetext{
${ }^{6}$ The training voucher award intensity is calculated as the number of awarded vouchers as a proportion of the stock of unemployed individuals.

${ }^{7}$ Descriptive statistics can be found in Table 1 .
}

agency districts and those in the southern part of the country on the borders of Switzerland and France exhibit very low intensities for almost all years.

The regional variation in the conditional award intensity is illustrated in Fig. 3. As defined in Eq. 2, the conditional award intensity is the variation that remains after we have conditioned on time-varying and time-constant regional differences. Light-colored employment agency districts have a negative conditional award intensity, indicating that their award intensity is below average. The opposite applies for dark-colored employment agency districts. The results do not suggest any concentration of particulary high or low conditional award intensities in specific regions or any specific pattern of intensities. The existence of neighboring employment agencies with very high and very low conditional voucher award intensities within the same federal states yields an interesting source of variation.

\subsection{Regional characteristics}

The description of local labor market conditions is based on a large set of annual regional characteristics. Descriptive statistics can be found in Table 1. Focussing on the average characteristics of the unemployment stock, we find that over $60 \%$ are middle-aged (25-54 years old) and most of the unemployed individuals have a German citizenship. The share of long-term unemployed is $18 \%$. We observe a variation between employment agencies and a variation over time regarding the characteristics. We present the average characteristics separately for each year under investigation. The share of young individuals aged between 15 and 24 years remains fairly constant whereas the share of older individuals aged between 55 and 64 increases by nearly 12 percentage points from 2005 to 2010 . The share of long-term unemployed decreases by 8 percentage points.

In addition to characteristics that describe the regional composition of the unemployment stock, it is also important to control for the regional composition of employees in different industries. We find that the largest shares work in manufacturing (26.8\%), trade (14.8\%), real estate $(11.2 \%)$ and the health and social sectors $(12.6 \%)$. The development over time shows a stable pattern. ${ }^{8}$

\footnotetext{
${ }^{8}$ In the time period that we focus on, the classification of industries in Germany changed and a new classification system was implemented in 2008. To avoid problems associated with the re-classification for our estimations (e.g. missing data), we re-weight the values of the new classification to the old classification. For this purpose, we use data from 2008, where we have information for both classification systems. We estimate the following equation

$$
\hat{y}_{j}=\hat{\alpha}+\sum_{i=1}^{n} \hat{\beta}_{i j} x_{i},
$$



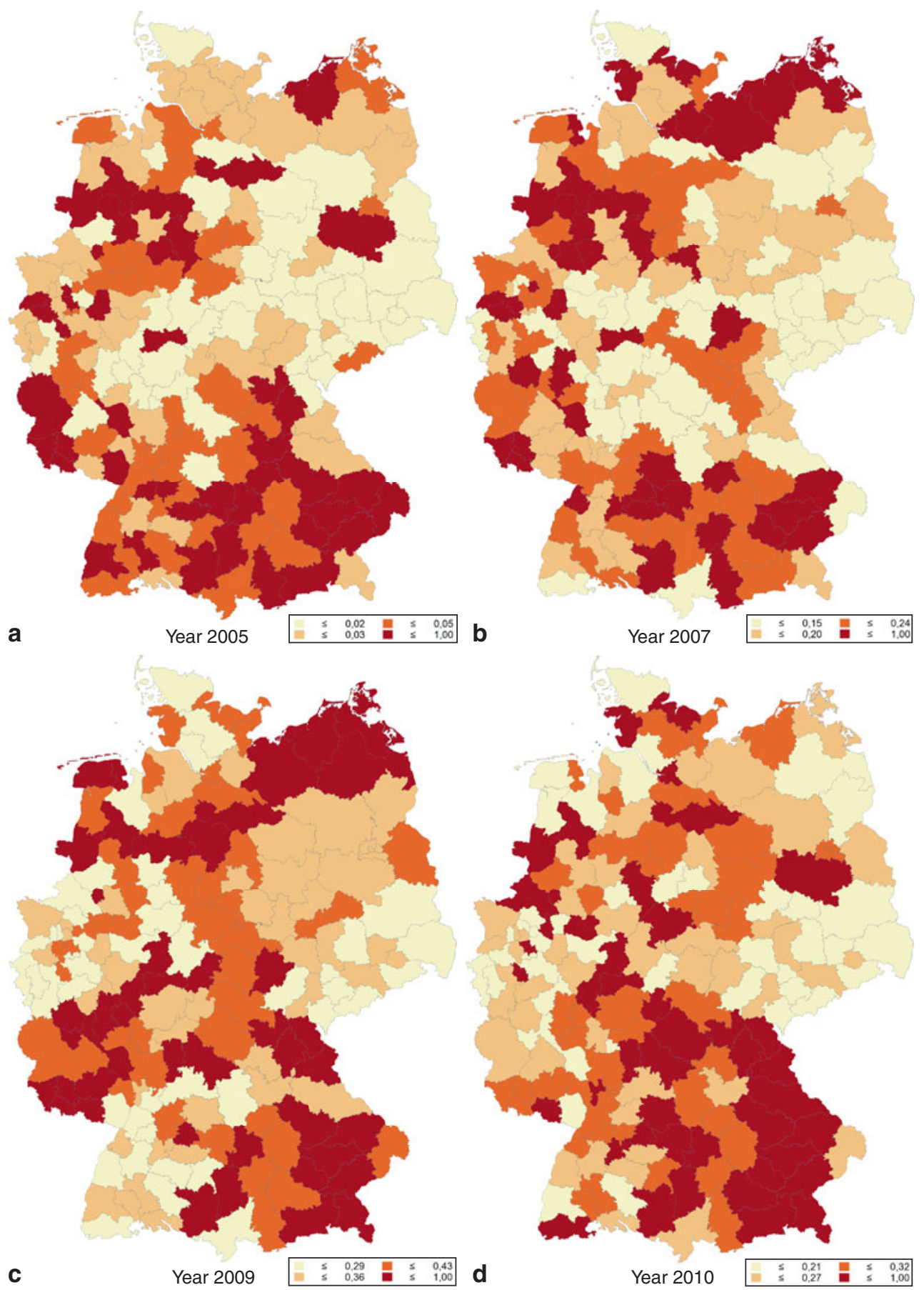

Fig. 2 Maps of voucher award intensity in the years 2005-2010. (Note: The variation of the voucher award intensity is presented in quartiles to facilitate comparisons between different years. Light-colored employment agencies districts have low intensities, dark-colored districts are those with high voucher award intensities).

where $j=1, \ldots, 18$ is an indicator for the industries according to the old classification and $i=1, \ldots, 22$ indicates the industries according to the new classification. To re-weight the new data, we estimate 18 regressions to obtain 396 weights $\beta_{i j}$.

\subsection{Policy-style characteristics}

We use unique survey data to characterize the error term, which we name policy style. At the beginning of 2011, a nationwide online survey was conducted in all local em- 

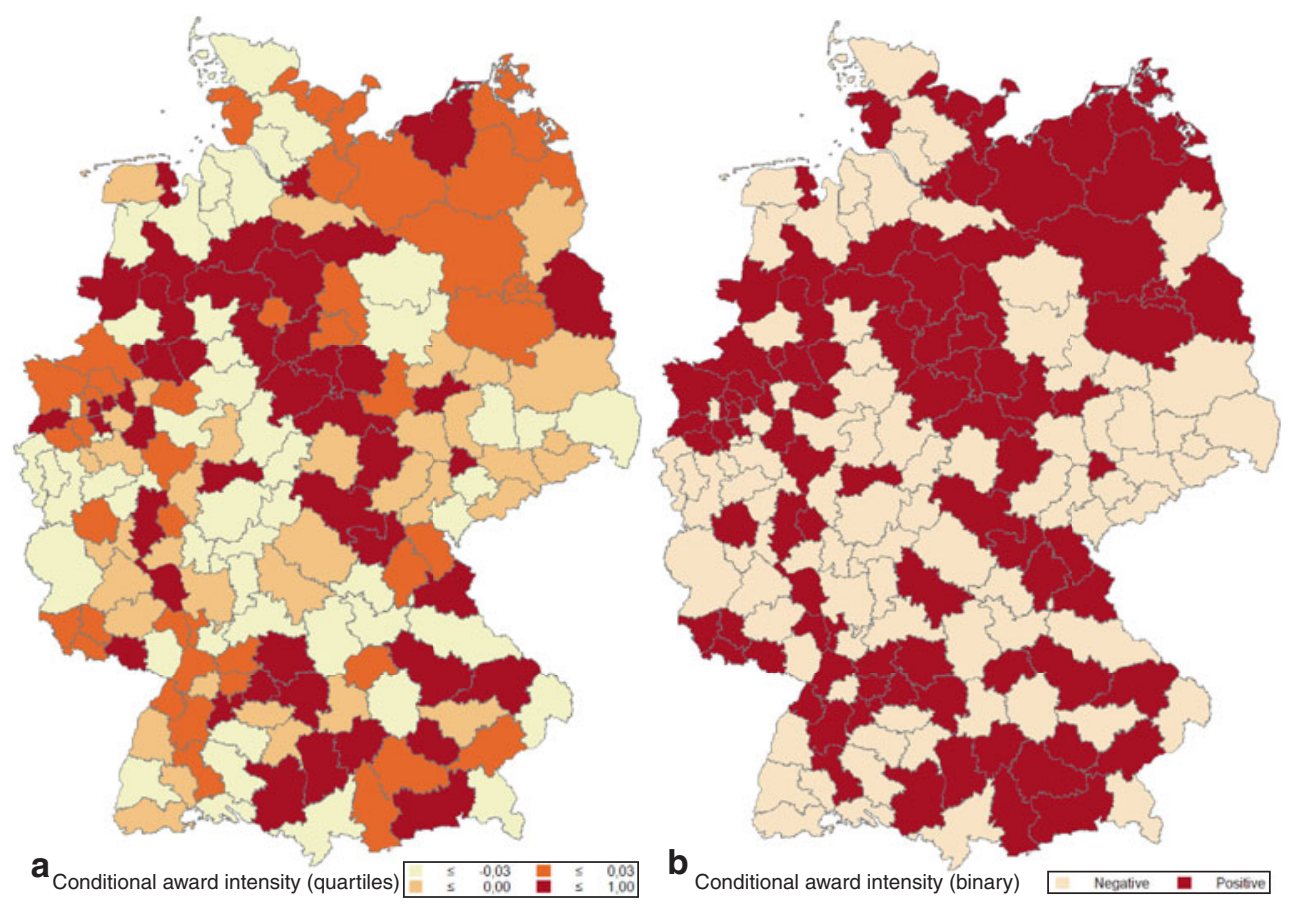

Fig. 3 Maps of conditional voucher award intensity. (Note: We present the conditional voucher award intensity in quartiles and as a binary indicator variable. In the binary case, light-colored districts are those whose agencies show below-average intensity, and dark-colored districts have agencies with above-average intensities).

ployment agencies in order to gain information about the procedures that are involved in the decisions about the use of training vouchers as one of a set of active labor market programs in Germany. Caseworkers and managers were asked to participate in the survey. The participation rate was remarkably high $(43.6 \%)$ compared to other online surveys. The survey yields information from 376 managers and 652 caseworkers. A detailed description of the survey implementation can be found in Doerr and Kruppe (2012).

Information from the online survey is used to form indicators that are likely to characterize the policy style of local employment agencies with regard to the use of training vouchers and quality management systems. The choice of indicators is motivated by studies from political science and adapted to the specific setting in the present investigation. Caseworkers' and managers' assessments of the reform serve as one indicator of the policy style. Furthermore, we focus on the degree of cooperation and communicative behavior, the internal organization and the use of avoidance strategies.

We construct the indictors at the level of employment agencies. ${ }^{9}$ Most of the questions can be analyzed as binary variables or are scaled on a 5-point Likert scale. To con-

${ }^{9}$ We aggregate the information from the survey at the level of employment agencies. Since the number of participating caseworkers and struct the policy-style indicators we calculate the averages for the corresponding questions, which are always measured on the same scale. Descriptive statistics for the specific questions and the indicators are presented in Table 2. We report means across all 173 local employment agencies as well as the means of employment agencies with high and low conditional award intensities, separately.

Reform assessment: The survey contains direct questions about the assessment of the reform activities. The findings suggest that the reform activities are assessed positively in most employment agencies. There are some minor differences in the assessment of different parts of the reform. If we focus on the assessment of employment agencies with low and high conditional award intensities, we find that those agencies with high conditional intensities assess the reform activities more positively.

Degree of cooperation: Information regarding the degree of cooperation with training providers is summarized in the cooperation indicator. The survey includes several questions about the cooperation between training providers and

managers differs between employment agencies, we use weights in all calculations. 
Table 1 Summary statistics of regional characteristics

\begin{tabular}{|c|c|c|c|c|c|c|c|c|c|}
\hline & Mean & Min & Max & 2005 & 2006 & 2007 & 2008 & 2009 & 2010 \\
\hline \multicolumn{10}{|l|}{ Share of unemployed } \\
\hline Aged 15-24 years (SGB III only) & 0.149 & 0.086 & 0.221 & 0.149 & 0.138 & 0.150 & 0.157 & 0.158 & 0.139 \\
\hline Aged 55-64 years (SGB III only) & 0.191 & 0.097 & 0.407 & 0.147 & 0.173 & 0.171 & 0.185 & 0.203 & 0.265 \\
\hline German citizenship (SGB III only) & 0.909 & 0.687 & 0.995 & 0.907 & 0.911 & 0.911 & 0.907 & 0.905 & 0.914 \\
\hline Long-term unemployment & 0.184 & 0.034 & 0.446 & 0.222 & 0.252 & 0.236 & 0.143 & 0.106 & 0.144 \\
\hline \multicolumn{10}{|l|}{ Share of employed } \\
\hline Management of forests and agriculture & 0.014 & 0.001 & 0.061 & 0.014 & 0.014 & 0.014 & 0.014 & 0.015 & 0.013 \\
\hline Mining & 0.005 & 0.000 & 0.066 & 0.005 & 0.005 & 0.005 & 0.005 & 0.005 & 0.004 \\
\hline Manufacturing industry & 0.268 & 0.089 & 0.827 & 0.273 & 0.270 & 0.270 & 0.270 & 0.270 & 0.253 \\
\hline Energy and water supply & 0.009 & 0.000 & 0.029 & 0.009 & 0.009 & 0.009 & 0.009 & 0.009 & 0.009 \\
\hline Construction & 0.063 & 0.018 & 0.118 & 0.064 & 0.064 & 0.064 & 0.062 & 0.063 & 0.061 \\
\hline Trade & 0.148 & 0.050 & 0.234 & 0.150 & 0.149 & 0.148 & 0.147 & 0.147 & 0.145 \\
\hline Hotels and restaurants & 0.028 & 0.007 & 0.101 & 0.028 & 0.027 & 0.028 & 0.028 & 0.029 & 0.028 \\
\hline Transport and communication & 0.053 & 0.000 & 0.242 & 0.052 & 0.052 & 0.053 & 0.053 & 0.052 & 0.054 \\
\hline Banking and insurance & 0.030 & 0.000 & 0.124 & 0.031 & 0.031 & 0.029 & 0.028 & 0.029 & 0.032 \\
\hline Real estate activities & 0.112 & 0.039 & 1.295 & 0.100 & 0.105 & 0.111 & 0.114 & 0.117 & 0.126 \\
\hline Public administration and defense & 0.063 & 0.019 & 0.155 & 0.066 & 0.065 & 0.063 & 0.062 & 0.063 & 0.062 \\
\hline Education & 0.038 & 0.010 & 0.112 & 0.038 & 0.037 & 0.037 & 0.037 & 0.041 & 0.038 \\
\hline Health-care and social sector & 0.126 & 0.043 & 0.214 & 0.125 & 0.125 & 0.124 & 0.125 & 0.130 & 0.129 \\
\hline Services & 0.041 & 0.011 & 0.132 & 0.040 & 0.040 & 0.040 & 0.040 & 0.047 & 0.043 \\
\hline Extraterritorial organisations and bodies & 0.001 & 0.000 & 0.060 & 0.001 & 0.001 & 0.001 & 0.001 & 0.001 & 0.001 \\
\hline \multicolumn{10}{|l|}{ Other characteristics } \\
\hline Unemployment rate & 0.105 & 0.027 & 0.289 & 0.116 & 0.128 & 0.117 & 0.097 & 0.084 & 0.090 \\
\hline Seasonal variance & 0.185 & 0.031 & 0.730 & 0.214 & 0.167 & 0.144 & 0.192 & 0.209 & - \\
\hline Dummy eastern Germany & 0.195 & 0.000 & 1.000 & & & & & & \\
\hline
\end{tabular}

Note: The information about seasonal variance is only available for 2005-2009.

employment agencies with regard to participants in training courses. Descriptive statistics show that cooperation is more intensive in agencies with high conditional award intensities.

Internal organization: The survey contains only a few questions that may reflect the internal organization. First it asks if employees in the agencies are trained for the new quality management system introduced during the reform. The second question relates to quality controls of training courses, for which the employment agencies continue to be responsible. The third question asks about the existence of a contact person should questions or problems arise regarding the new instruments. The results show that those agencies with a positive conditional award intensity have a lower degree of organization measured by these three proxies. Agencies which are better organized have a lower conditional award intensity. A high degree of organization may reflect better knowledge about the new system, since the proxies we use are strongly related to the new quality management system. As found by Doerr and Kruppe (2012), caseworkers and managers have negative attitudes towards the new certification system, especially towards the quality management and private certification bodies. It is possible that those who are better informed assess the new system more negatively, resulting in a lower award intensity of vouchers. Indeed, we find a more negative assessment for the agencies that are better organized in terms of the three proxies.

Degree of communication: Another important dimension of policy style is the degree of communication. The survey includes various questions about communication with the other institutions involved (i.e. with the private certification bodies or the Federal Employment Agency). Those agencies with high conditional intensities communicate more frequently with the other institutions involved. This is expected from the policy-style literature since a large degree of communication reflects openness towards a policy instrument. There are some differences between the questionnaires for managers and caseworkers with respect to the question selection. Since managers perform more strategic work in the backoffice they were asked some additional questions. If we focus solely on the communicative behavior of managers, the difference between employment offices with high and low conditional intensities is somewhat more pronounced. 


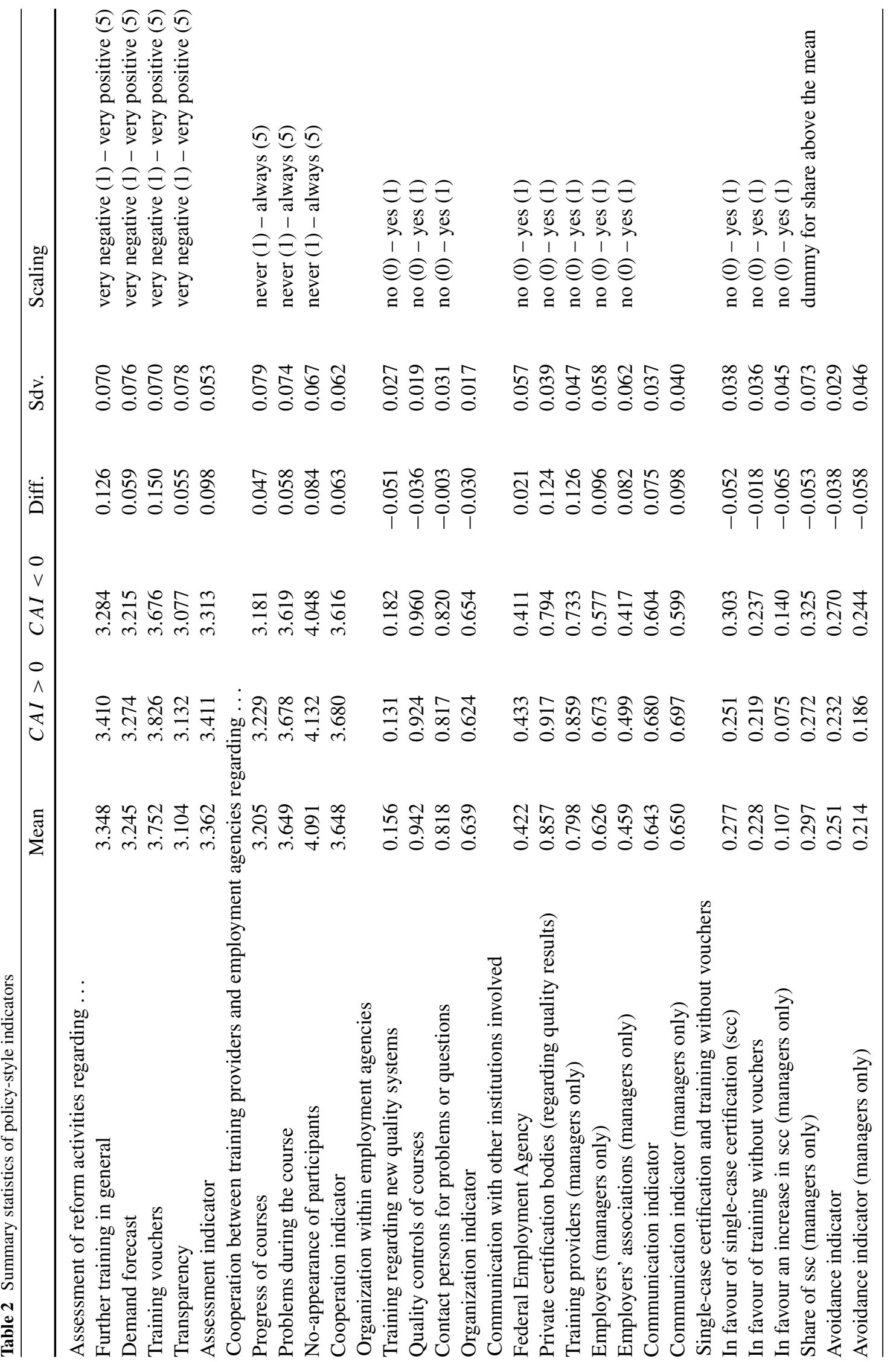




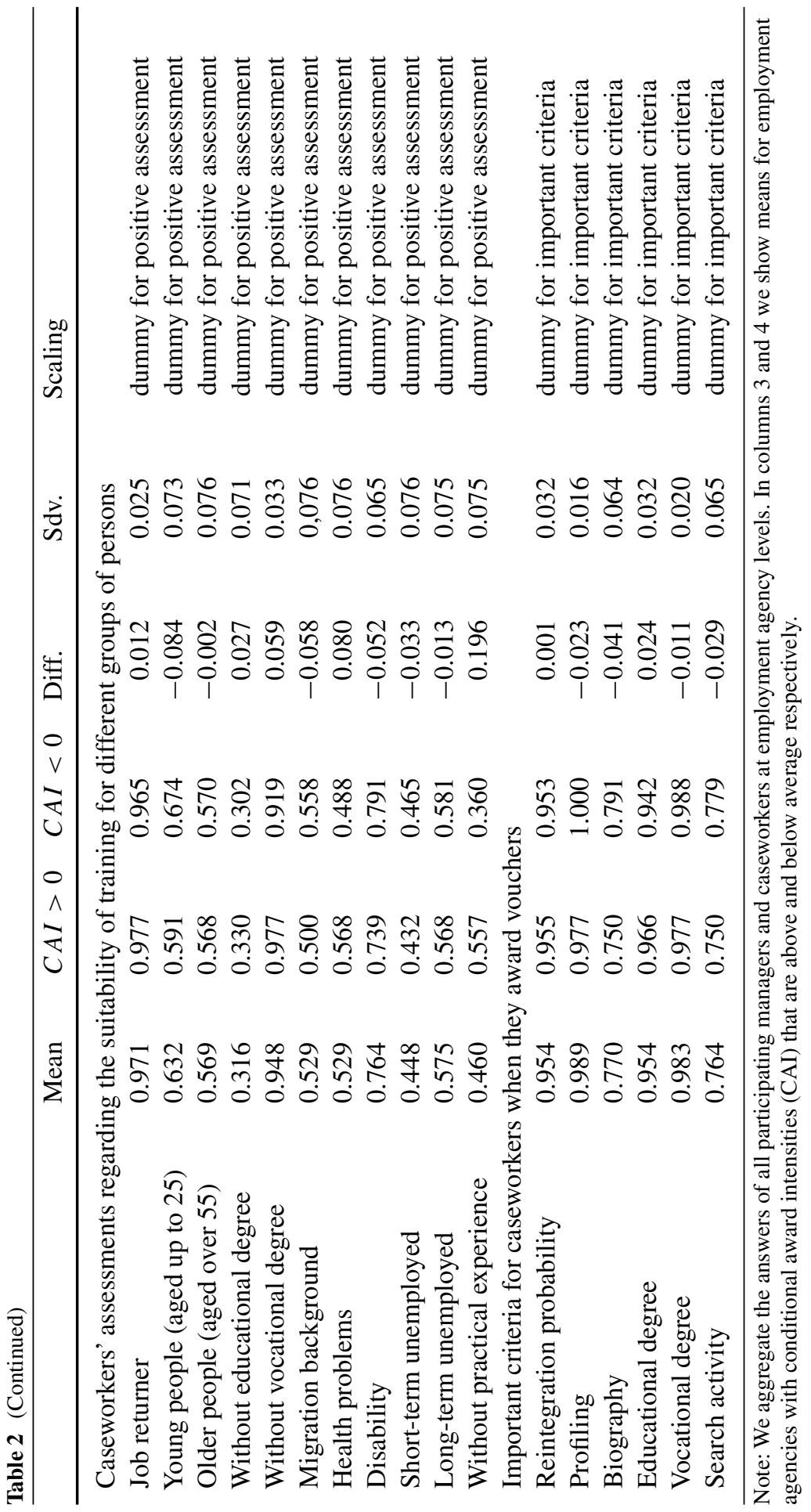


Avoidance strategy: As mentioned earlier, there are reasons for caseworkers and managers possibly disliking the new system. In the survey data Doerr and Kruppe (2012) found some indication of negative attitudes. This should be reflected by the avoidance parameter that is expected to be negatively correlated with the conditional award intensities. We measure avoidance by means of questions asking if an increase in training without vouchers and an increase in singlecase certifications has been requested. ${ }^{10}$ Indeed, we find that employment agencies with negative conditional award intensities use these avoidance strategies more often. This result is substantiated when we use the information provided solely by managers.

The online survey contains very interesting information about the assignment practice within the employment agencies. Caseworkers and managers were asked to evaluate which groups of persons they favor as potential candidates for a voucher award. Descriptive statistics in Table 2 show that job returners and individuals without schooling degree are assessed as the most suitable participants. Questions about the importance of assignment criteria detect the reintegration probability, the profiling results as well as educational achievement as the most important factors. We use this information as additional control variables in the estimations.

\section{Results}

\subsection{Regression results}

First, we discuss the influence of regional characteristics on the voucher award intensity. The coefficients obtained by estimating Eq. (1) are reported in Table 3. In the upper part of the table we report the time-varying influence of the regional characteristics. In the lower part, we show the influence of time-constant levels. We only include time-varying variables in the regression if the variance over time is large enough to avoid multi-collinearity problems.

The time-varying influence of the (lagged) unemployment rate shows a positive and highly significant coefficient. Employment agencies that experience an increase in the unemployment rate over time award more vouchers.

We find a negative correlation between the share of young unemployed and the voucher award intensity over time. The

\footnotetext{
${ }^{10}$ Single-case certifications are used to take into account very specific individual needs, for example if there is no certified course for the specific training and, furthermore, there seems to be no further demand for it. The course can then be certified by the agency itself. This (and other regulations) have been used contrary to the rules from employment agencies to avoid both the use of vouchers and the certification of training providers. A detailed explanation of these tools can be found in Doerr and Kruppe (2012).
}

Table 3 Regression results for time-variant and time-constant regional characteristics

\begin{tabular}{lrl}
\hline \multicolumn{3}{l}{ Dependent Variable: Annual voucher award intensity } \\
& Coef. & Std. Dev. \\
\hline $\begin{array}{l}\text { Time-varying variables } \\
\text { Lagged unemployment rate }\end{array}$ & $\mathbf{0 . 5 5 4}$ & $(0.179)$ \\
Registered unemployed, shares & \\
Aged 15-24 & $\mathbf{- 1 . 2 3 3}$ & $(0.326)$ \\
Aged 55-64 & $\mathbf{0 . 3 7 5}$ & $(0.174)$ \\
With German citizenship & 0.833 & $(0.533)$ \\
Long-term unemployed & $-\mathbf{0 . 4 9 5}$ & $(0.116)$ \\
Time-constant variables & & \\
Eastern Germany & -0.027 & $(0.029)$ \\
Lagged unemployment rate & -0.511 & $(0.311)$ \\
Seasonal variance & $\mathbf{0 . 2 3 8}$ & $(0.086)$ \\
Registered unemployed, shares & & \\
Aged 15-24 & $\mathbf{1 . 1 9 4}$ & $(0.457)$ \\
Aged 55-64 & -0.082 & $(0.373)$ \\
Long-term unemployed & -0.170 & $(0.243)$ \\
German citizenship & -0.739 & $(0.531)$ \\
Industry structure & Yes \\
Year dummies & Yes & \\
\hline
\end{tabular}

Note: We report robust standard errors in parentheses. Bold numbers indicate significance at least at the 5\% level.

level effects show that employment agencies with large shares of young unemployed award on average more vouchers. From human capital theory we expect these result because investments in young training participants can yield returns over a very long period. On the other hand, there are a lot of special programs targeting to young unemployed. This may explain the negative correlation over time. Each employment agency has a certain fixed budget that can be allocated to different programs. If the share of young unemployed rises over time, more of the budget will potentially be allocated to special programs for young individuals.

Increasing shares of older registered unemployed and decreasing shares of long-term unemployed also lead to more vouchers being awarded. Furthermore, on average the voucher award intensity is highly correlated with high seasonal patterns in the unemployment rate reported by the employment agencies ..$^{11}$

The variation in the voucher award intensity that remains after we have controlled for regional and labor market characteristics can be defined as the conditional award intensity (see Sect. 4.3). The characterization of the conditional award intensity by policy-style indicators is of interest in this paper. The regression results are presented in Table 4.

\footnotetext{
${ }^{11}$ Depending on the regional economic structure the unemployment rate can be subject to strong seasonal fluctuations, for example if there is a large share of employment in tourism.
} 


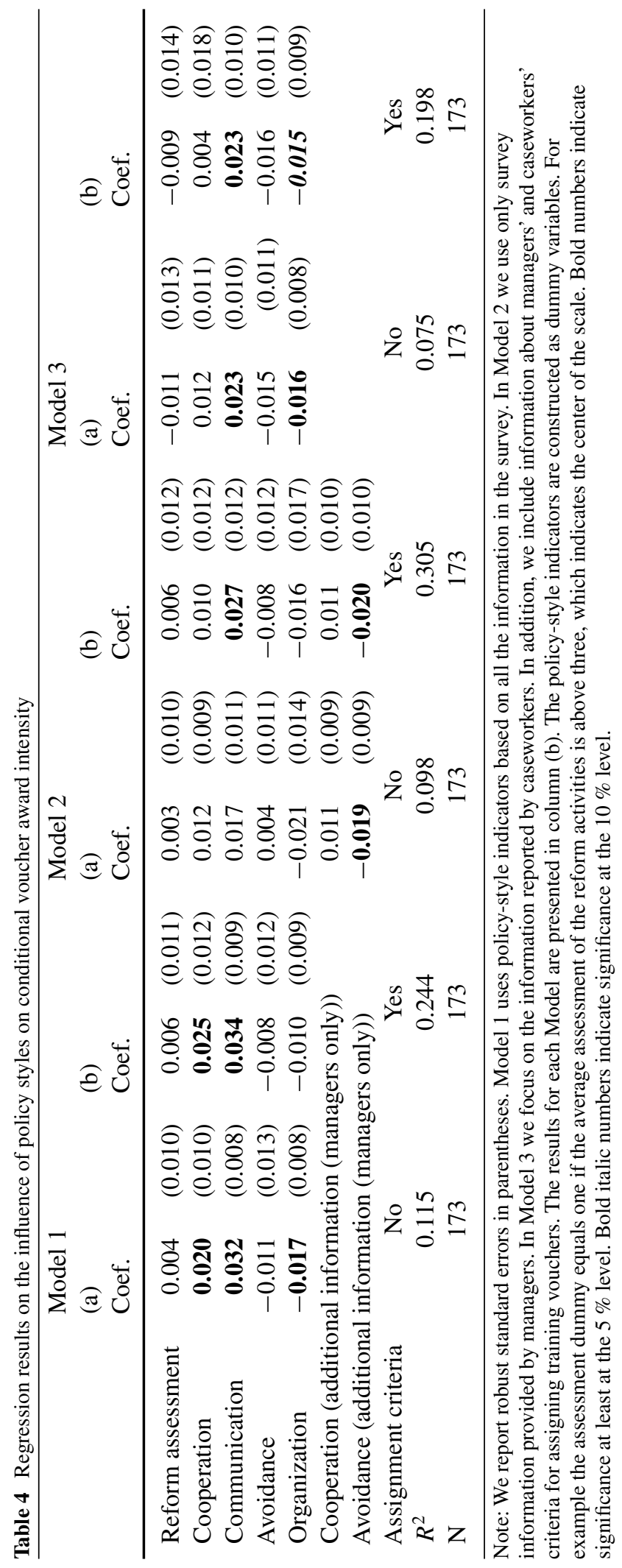


The estimated effects should be interpreted as correlations. Nevertheless, we report the size of the coefficients to provide some idea of the magnitudes of the correlations. In the following we rely only on significant results. In Model 1 we use the policy-style indicators from the survey information provided by all participating caseworkers and managers. In Models 2 and 3 we use the survey information reported by managers and caseworkers separately. Different results may be obtained if we rely on policy-style indicators based on answers given by different authorities.

We find that the cooperation and communication indicator has positive and mainly significant effects on the conditional voucher intensity, amounting to approximately 2-3 vouchers per 100 unemployed individuals. The organization indicator shows negative effects of 1.5-2 vouchers per 100 unemployed persons. As stated earlier, the negative influence was not expected a priori but can be explained by an observed negative correlation between internal organization and the assessed quality management systems. Both the avoidance indicator and the reform assessment show the expected sign in most cases, but the coefficients are very small with large standard errors. If we focus on policy-style indicators based on answers given by managers, we can use two more indicators, because managers had to answer more specific questions in the survey. The results show that the point estimates of the cooperation and communication indicator are smaller and not significant in most cases in this sample. Instead, the avoidance strategy becomes more important. We find a negative influence of about 2 vouchers per 100 unemployed, implying that these agencies award fewer vouchers.

We incorporate the information about the assignment practice into the regressions even though this information is not directly related to the implementation of the voucher and quality management systems. The results are presented for all models in column (b). The results are generally not sensitive with regard to this information. We conclude that the influence of policy styles measured by indicators for cooperative and communicative behavior as well as the degree of organization seems to be robust. In the main specifications we find a significant positive correlation between the degree of cooperative and communicative behavior and the voucher award intensity of employment agencies. The correlation between voucher awards and the degree of internal organization is negative.

\subsection{Sensitivity of results}

There are good reasons why the assumption of time-constant policy styles may be violated. In this study we have the possibility to use unique online survey data that were collected in 2011. Unfortunately, these data are not available for earlier years. It is therefore not possible to control for time-variant effects of the policy-style indicators. To check the robustness
Table 5 Sensitivity analysis with regard to tenure

\begin{tabular}{lrrrr}
\hline & (a) & \multicolumn{3}{l}{ (b) } \\
& Coef. & \multicolumn{3}{l}{ Coef. } \\
\hline Reform assessment & 0.006 & $(0.012)$ & 0.011 & $(0.013)$ \\
Cooperation & -0.004 & $(0.009)$ & -0.002 & $(0.012)$ \\
Communication & $\mathbf{0 . 0 2 3}$ & $(0.010)$ & $\mathbf{0 . 0 2 7}$ & $(0.009)$ \\
Avoidance & -0.003 & $(0.012)$ & -0.009 & $(0.012)$ \\
Organization & -0.008 & $(0.009)$ & -0.012 & $(0.009)$ \\
Assignment criteria & \multicolumn{3}{c}{ No } & \multicolumn{2}{c}{ Yes } \\
$R^{2}$ & \multicolumn{2}{c}{0.075} & \multicolumn{2}{c}{0.261} \\
$N$ & \multicolumn{2}{c}{169} & \multicolumn{2}{c}{169} \\
\hline
\end{tabular}

Note: We report robust standard errors in parentheses. We include survey information provided by caseworkers and managers with a tenure of at least 5 years. Bold numbers indicate significance at least at the $5 \%$ level. Bold italic numbers indicate significance at the $10 \%$ level.

of the presented results, we perform several tests. First, we use only survey data information provided by caseworkers and managers with a tenure of more than 5 years (see Table 5). The assumption of time-constant policy styles is more likely to hold in this sample. Second, we changed the time period for which we calculate the conditional award intensities. We calculated the intensities close to the time when the reform was introduced (2005-2006) and at a later time (2009-2010) to determine whether the influence of the policy-style indicators changes when we explain the variation in conditional voucher award intensities for earlier or more recent years. The results are presented in Table 6. Third, we use only employment agencies with conditional award intensities above the third and below the first quartile to find out whether the influence is stronger for those employment agencies (see Table 7). If the influence does not change in size, there might be other factors that drive the very high or low conditional award intensities.

The influence of the significant indicators is most of the time stable with regard to direction and size. In the first test, the effect of the communication indicator is very robust and still highly significant. The point estimates of the other indicators are much smaller and mostly insignificant. The same happens when we examine the time span closer to the reform. Using the sample further from the time of the reform we obtain very robust results. As expected, we find higher magnitudes for the third test. A high degree of cooperation and communication increases the award intensity for these agencies by almost six vouchers per 100 unemployed. Accordingly, we conclude that the effects of the policy-style indicators are robust in most of the different specifications.

\section{Conclusions}

The variation in voucher award intensity is the main interest of this paper. We observe a considerable variation in the 
Table 6 Sensitivity analysis with regard to time period

\begin{tabular}{|c|c|c|c|c|}
\hline & $\begin{array}{l}\text { (a) } \\
\text { Coef. }\end{array}$ & & $\begin{array}{l}\text { (b) } \\
\text { Coef. }\end{array}$ & \\
\hline Close to Reform & & & & \\
\hline $\begin{array}{l}\text { Reform } \\
\text { assessment }\end{array}$ & 0.010 & $(0.007)$ & 0.010 & $(0.007)$ \\
\hline Cooperation & 0.003 & $(0.008)$ & 0.006 & $(0.008)$ \\
\hline $\begin{array}{l}\text { Communi- } \\
\text {-cation }\end{array}$ & 0.020 & $(0.006)$ & 0.021 & $(0.007)$ \\
\hline Avoidance & -0.004 & $(0.008)$ & -0.003 & $(0.008)$ \\
\hline Organization & -0.010 & $(0.005)$ & -0.006 & $(0.006)$ \\
\hline $\begin{array}{l}\text { Assignment } \\
\text { criteria }\end{array}$ & \multicolumn{2}{|c|}{ No } & \multicolumn{2}{|c|}{ Yes } \\
\hline$R^{2}$ & \multicolumn{2}{|c|}{0.181} & \multicolumn{2}{|c|}{0.368} \\
\hline$N$ & \multicolumn{2}{|c|}{87} & \multicolumn{2}{|c|}{87} \\
\hline \multicolumn{5}{|l|}{ Far from Reform } \\
\hline $\begin{array}{l}\text { Reform } \\
\text { assessment }\end{array}$ & -0.004 & $(0.014)$ & -0.003 & $(0.015)$ \\
\hline Cooperation & 0.032 & $(0.018)$ & 0.042 & $(0.020)$ \\
\hline $\begin{array}{l}\text { Communi- } \\
\text {-cation }\end{array}$ & 0.023 & $(0.012)$ & 0.025 & $(0.013)$ \\
\hline Avoidance & -0.017 & $(0.016)$ & -0.014 & $(0.016)$ \\
\hline Organization & -0.012 & $(0.012)$ & -0.006 & $(0.011)$ \\
\hline $\begin{array}{l}\text { Assignment } \\
\text { criteria }\end{array}$ & \multicolumn{2}{|c|}{ No } & \multicolumn{2}{|c|}{ Yes } \\
\hline$R^{2}$ & \multicolumn{2}{|c|}{0.060} & \multicolumn{2}{|c|}{0.186} \\
\hline$N$ & \multicolumn{2}{|c|}{173} & \multicolumn{2}{|c|}{173} \\
\hline
\end{tabular}

Note: We report robust standard errors in parentheses. We calculate the conditional award intensities for the years 2005-2006, shortly after the reform was introduced. We repeat the test for years more distant from the reform but close to the time period in which the survey took place. Bold numbers indicate significance at least at the $5 \%$ level. Bold italic numbers indicate significance at the $10 \%$ level.

number of awarded vouchers across employment agencies in Germany. These intensities are likely to vary with regional labor market conditions. Different policy styles of employment agencies may also have an influence on the awarding behavior. In this study we use unique survey data that permit us to form policy-style indicators of employment agencies. We perform simple regressions to show that policy-style indicators are correlated with the intensity of awarded vouchers after we control for time-variant and time-constant labor market conditions.

The results obtained suggest that communicative behavior and a high degree of cooperation are positively correlated with conditional voucher award intensities. If we focus on the survey information provided by managers, we find a negative correlation between the importance of avoidance strategies and the use of training vouchers as one instrument of ALMP in Germany. The sensitivity tests performed mainly confirm the robustness of our results.
Table 7 Sensitivity analysis for agencies with very low and high voucher intensities

\begin{tabular}{lrrrr}
\hline & (a) & \multicolumn{3}{c}{ (b) } \\
& Coef. & \multicolumn{3}{c}{ Coef. } \\
\hline Reform assessment & -0.007 & $(0.020)$ & -0.003 & $(0.025)$ \\
Cooperation & $\mathbf{0 . 0 5 4}$ & $(0.020)$ & $\mathbf{0 . 0 6 3}$ & $(0.032)$ \\
Communication & $\mathbf{0 . 0 5 8}$ & $(0.015)$ & $\mathbf{0 . 0 5 7}$ & $(0.018)$ \\
Avoidance & -0.016 & $(0.024)$ & -0.020 & $(0.022)$ \\
Organization & $-\mathbf{0 . 0 2 7}$ & $(0.015)$ & -0.022 & $(0.017)$ \\
Assignment criteria & \multicolumn{2}{c}{ No } & \multicolumn{2}{c}{ Yes } \\
$R^{2}$ & \multicolumn{2}{c}{0.181} & \multicolumn{2}{c}{0.368} \\
$N$ & \multicolumn{2}{c}{87} & \multicolumn{2}{c}{87} \\
\hline
\end{tabular}

Note: We report robust standard errors in parentheses. We include in the regression only agencies with voucher intensities below the first and above the third quartile. Bold numbers indicate significance at least at the $5 \%$ level. Bold italic numbers indicate significance at the $10 \%$ level.

In this paper we focus solely on correlations between policy styles and the voucher award intensity of local employment agencies. As is argued in Bauer and Kruppe (2013), policy styles are by no means a single phenomenon. The relationship between other ALMP measures and policy styles would therefore be a suitable question for further research.

\section{Kurzfassung}

In Rahmen dieser Studie untersuchen wir den Zusammenhang von Politikstilen örtlicher Arbeitsagenturen und der Vergabeintensität von Bildungsgutscheinen, einem der wichtigsten Instrumente der aktiven Arbeitsmarktpolitik in Deutschland. Ausgangspunkt ist eine hohe regionale Heterogenität im Hinblick auf die Vergabe von Bildungsgutscheinen. Neben regionalen und arbeitsmarktspezifischen Unterschieden könnte auch ein agenturspezifischer Politikstil die Ausgabeintensität der Gutscheine beeinflussen.

Im Hinblick auf die Definition des Politikstils beziehen wir uns auf aktuelle Literatur aus der Politikwissenschaft zu diesem Thema. In diesem Sinne verstehen wir den Politikstil einer Arbeitsagentur als deren Implementationsstil des Bildungsgutscheinsystems und des Qualitätssicherungsverfahrens. Empirisch definieren wir den Politikstil über die Bewertung von Arbeitsvermittler/innen und Teamleiter/innen in Bezug auf das Gutscheinsystem, die interne Organisation in den Arbeitsagenturen und deren Kooperations- und Kommunikationsverhalten sowie die Befürwortung von Umgehungsstrategien des Bildungsgutscheinsystems (z.B. durch Einzelfallzulassung).

Hintergrund der Idee, die Heterogenität der Ausgabeintensität mit dem Politikstil der Arbeitsagenturen in Verbindung zu bringen, ist die im Jahre 2003 durchgeführte Reform der geförderten Weiterbildung. Die Einführung von 
Bildungsgutscheinen als Quasi-Zahlungsmittel soll die Eigeninitiative und Verantwortung der Weiterbildungsteilnehmer durch eine höhere Freiheit bei der Auswahl einer geeigneten Bildungsmaßnahme erhöhen. Diese von den Weiterbildungsteilnehmern geforderte Eigenverantwortung und Initiative setzt allerdings voraus, dass ein entsprechendes quantitatives als auch qualitatives Angebot an Maßnahmen verfügbar ist. Die damit einhergehende Notwendigkeit eines transparenten und übersichtlichen Weiterbildungsmarktes soll durch ein neues Qualitätssicherungsverfahren (Zertifizierung) gewährleistet werden.

Die Reform der geförderten beruflichen Weiterbildung hat somit weitreichende Folgen für Weiterbildungsteilnehmer, Bildungsanbieter und die Mitarbeitenden in der Arbeitsverwaltung. Durch die Reform kam es zu Veränderungen der Arbeitsabläufe und Handlungsvorgaben in den Dienststellen. Erstens wurde die direkte Zuweisung der Arbeitslosen zu passenden Bildungsträgern und Maßnahmen durch die Einführung des Bildungsgutscheins hinfällig. Zweitens wurde die Zulassung der Bildungsträger im Rahmen des Zertifizierungsprozesses ausgelagert.

Die Datenbasis dieser Studie besteht zum einen aus prozessproduzierten Daten der Bundesagentur für Arbeit über die jährliche Ausgabe von Bildungsgutscheinen zwischen den Jahren 2005 und 2010. Zum anderen können wir einzigartige Befragungsdaten nutzen, die einen Einblick über die Bewertung und die Umsetzung des Bildungsgutscheinsystems in den Arbeitsagenturen liefern. Wir kombinieren die Befragungsdaten mit Informationen zu den regionalen und arbeitsmarktspezifischen Eigenschaften der örtlichen Arbeitsagenturbezirke.

Aufgrund von Datenrestriktionen ist es im Rahmen dieser Studie nicht möglich den kausalen Effekt des Politikstils auf die Ausgabeintensität der Bildungsgutscheine zu identifizieren. Die präsentierten Korrelationen zeigen in den meisten von uns durchgeführten Sensitivitätsanalysen einen robusten Zusammenhang. Die Studie liefert somit einige interessante Hinweise über das Verhalten innerhalb der Arbeitsagenturen.

In einem ersten Schritt filtern wir den Einfluss der regionalen und arbeitsmarktspezifischen Eigenschaften auf die Variation in der Ausgabeintensität der Gutscheine heraus. Dabei unterstellen wir, dass es zeitvariable aber auch zeitkonstante Niveauunterschiede gibt. Mit Hilfe einfacher panelökonometrischer Methoden können wir diese Unterschiede herausrechnen.

Übrig bleibt eine zeitkonstante Variation in der bedingten Ausgabeintensität, die wir durch Unterschiede in den Politikstilen erklären. Unter Berücksichtigung regionaler und arbeitsmarktspezifischer Unterschiede der örtlichen Arbeitsagenturbezirke finden wir Hinweise darauf, dass Agenturen mit einer hohen Kommunikations- und Kooperationsbereitschaft durchschnittlich mehr Gutscheine ausgeben. Des Weiteren finden wir einen negativen Zusammenhang zwi- schen der Ausgabeintensität von Gutscheinen und dem Umgehungsverhalten von Teamleiter/innen. D.h., in Arbeitsagenturen in denen sich die Teamleiter/innen positiv zu Umgehungsstrategien geäußert haben, werden durchschnittlich weniger Bildungsgutscheine ausgegeben.

\section{References}

Battaglini, M., Giraud, O.: Policy styles and the swiss executive federalism: Comparing diverging styles of cantonal implementation of the federal law on unemployment. Swiss Polit. Sci. Rev. 9(1), 285-308 (2003)

Bauer, A., Kruppe, T.: Policy Styles - zur Genese des Politikstilkonzepts und dessen Einbindung in Evaluationsstudien. IAB-Discussion Paper 22 (2013)

Breedgard, T., Dalsgaard, L.: Flemming, L. An Alternative Approach for Studying Public Policy - The Case of Municipal Implementation of Active Labour Market Policy in Denmark. Working Paper from the Department of Economics, Politics and Public Administration, Aalborg University (2013)

Dann, S., Klee, G., Rosemann, M.: Vermittlungsgutscheine: Zwischenergebnisse der Begleitforschung 2004 Teil 2: Typisierung der Arbeitsagenturen. IAB-Forschungsbericht (2005)

Doerr, A., Kruppe, T.: Bildungsgutscheine und Zertifizierung aus Sicht der Arbeitsverwaltung - Umfrageergebnisse aus der Bundesagentur für Arbeit. IAB-Forschungsbericht (2012)

Doerr, A., Fitzenberger, B., Kruppe, T., Paul, M., Strittmatter, A.: The Award of a Training Vouchers: Employment and Earnings Effects. Working Paper (2014)

Knodt, M.: Die Prägekraft regionaler Politikstile. In: Kohler-Koch, B. (ed.) Interaktive Politik in Europa: Regionen im Netzwerk der Integration, pp. 97-124. Leske und Budrich, Opladen (1998)

Richardson, J.: Policy Styles in Western Europe. George Allen \& Unwinn London (1982)

Rinne, U., Uhlendorff, A., Zhao, Z.: Vouchers and caseworkers in training programs for the unemployed. Empirical Economics. 45(3), 1089-1127 (2013)

Sachverständigenrat für Bildung: Jugend, Bildung und Zivilgesellschaft - Anregungen zur Diskussion. Diskussionspapiere HansBlöckler Stiftung (1999)

Schiller, T.: Politikstil als vergleichendes Untersuchungskonzept. In: Michelmann, H., Schiller, T. (eds.) Politik und Politikstile im kanadischen Bundesstaat. Gesundheits- und energiepolitische Entscheidungsprozesse im Provinzenvergleich, pp. 33-53. Leske und Budrich, Opladen (1991)

Schneider, H., Brenke, K., Kaiser, L., Steinwede, J., Jesske, B., Uhlendorff, A.: Evaluation der Maßnahmen zur Umsetzung der Vorschläge der Hartz-Kommission - Modul 1b. IZA Research Report 2006 (2006)

Winterhager, H., Heinze, A., Spermann, A.: Deregulating job placement in europe: A microeconometric evaluation of an innovative voucher scheme in germany. Lab. Econ. 13(4), 505-517 (2006)

Wooldridge, J.: Econometric Analysis of Cross Section and Panel Data. 2nd edn. MIT Press, Cambridge, Massachusetts (2010)

Annabelle Doerr, is a research and teaching assistant at the Albert-Ludwigs University in Freiburg since 2009. She studied Economics at the Albert-Ludwigs University Freiburg and the Copenhagen Business School (CBS). From 20092013 she participated in the Graduate Program (GradAB) at the Institute for Employment Research (IAB). Her main rese- 
arch interests are in the evaluation of labor market programs, labor economics in general and applied econometrics.

Thomas Kruppe, studied sociology at Free University Berlin, where he also received his doctoral degree in 2003. Currently he is senior researcher and head of the working groups "Further Training" at the Institute for Employment
Research (IAB). From 2011 to 2013 he acted as Provisional Head of IAB's the Research Department "Education and Employment over the Life Course". His main research interests cover evaluation of labor market policies like further vocational training, short-time work or the provision of placement services. 